\title{
Ovarian remnant syndrome in the bitch: a literature review
}

\author{
Síndrome de remanente ovárico en la perra: revisión bibliográfica \\ B H Sontas ${ }^{1 *}$, K Gürbulak ${ }^{2}$, H Ekici $^{1}$ \\ ${ }^{1}$ Department of Obstetrics and Gynaecology, Faculty of Veterinary Medicine, \\ Istanbul University, Avcilar Campus, 34850, Avcilar, Istanbul, Turkey. \\ ${ }^{2}$ Department of Obstetrics and Gynaecology, Faculty of Veterinary Medicine, Erciyes University, Kayseri, Turkey.
}

\begin{abstract}
RESUMEN
El síndrome de ovario remanente es una complicación conocida y de larga duración de la ovariectomía u ovariohisterectomía, que es causada por la presencia de tejido ovárico activo a pesar de una cirugía electiva. Como resultado de dejar restos de tejido ovárico en el abdomen o debido a la presencia de tejido ovárico ectópico, se desarrollan signos clínicos típicos de proestro o estro tales como hinchazón de la vulva, sangramiento o cambios conductuales. El diagnóstico se realiza por citología vaginal, medición de hormonas gonadales, ultrasonografía y cirugía exploratoria. La excisión quirúrgica de la masa ovárica es el tratamiento recomendado, lo cual es un proceso difícil. Este trabajo describe las causas del síndrome, los signos clínicos del paciente, el diagnóstico y el tratamiento del síndrome de ovario remanente en perras.
\end{abstract}

Palabras clave: perro, ovariohisterectomía, estro postoperación, sangramiento vaginal

Key words: dog, ovariohysterectomy, post-operative oestrous, vaginal bleeding

\section{INTRODUCTION}

Surgical sterilization of domestic animals has been performed for many centuries and it is considered to be the most common, reliable, effective and the least controversial contraception method (Concannon and MeyersWallen 1991, Salmeri et al 1991, Concannon 1995). Ovariectomy $(\mathrm{OVX})$ and ovariohysterectomy $(\mathrm{OVH})$ are the two surgical techniques routinely performed for the surgical sterilization of female animals. Since general anaesthesia, laparotomy and organ removal are performed during the surgeries, complications related to these issues like anaesthetic problems, haemorrhage, dehiscence, delayed wound healing, suture abscesses and infections are similar to any abdominal surgery (Pearson 1973, Dorn and Swist 1977, Okkens et al 1981 ${ }^{\mathrm{a}-\mathrm{b}}$, Johnston 1991, Stone et al 2003, Pollari et al 1996, Okkens et al 1997).

Ovarian remnant syndrome (ORS) is a specific longterm complication of OVH when the ovarian cortex is not fully removed. This syndrome is an iatrogenic condition rather than a spontaneous pathological disorder (Wallace 1991). The first case report in humans was published in 1962 by Kaufmann however the syndrome was first described by Shemwell and Weed in 1970. In 1973,

Aceptado: 14.05.2007.

* Corresponding Author: Hasan Sontas, DVM, Ph.D, Department of Obstetrics and Gynaecology, Faculty of Veterinary Medicine, Istanbul University, 34320, Avcilar, Istanbul, Turkey. Telephone: +90532-324-37-13. E-mail: bhsontas@gmail.com
Pearson published the first ORS report in companion animals with 12 cases.

In this paper, aetiology, clinical presentation, diagnosis and treatment options for ORS in the bitch will be reviewed.

\section{AETIOLOGY OF ORS}

The mechanism of the syndrome was first described by Shemwell and Weed (1970), who showed that the ovarian cortex could be functional if implanted elsewhere in the abdomen rather than in its anatomical origin. These authors implanted the cortex of the excised ovaries of four female cats into the peritoneum of the lateral abdominal wall. Four months later, they observed that two cats had exhibited signs of oestrous and the other two had ovarian cysts with follicular activity. The residual ovarian tissue continues to be functional and causes clinical signs of proestrous, oestrous, false pregnancy or even mating that ends with no pregnancy, in spite of the surgery. Remnant ovarian tissue may affect the life quality or may shorten the life span of the animal because it may promote the development of granulosa cell tumors or mammary neoplasias (Pluhar et al 1995, Sangster 2005).

It appears that ovarian remnant syndrome is a more frequent complication of $\mathrm{OVH}$ in women than in companion animals perhaps because $\mathrm{OVH}$ is more commonly performed on healthy animals with no reproductive pathology (Miller 1995, Prats 2001). In women, ORS may develop after a difficult oophorectomy which may be due 
to an increased vascularity as a result of endometriosis or pelvic inflammatory disease (PID), to pelvic adhesions or to anatomical changes caused by neoplasms or after an incomplete laparoscopic oophorectomy (Shemwell and Weed 1970, Lafferty et al 1996, Kamprath et al 1997, Nezhat et al 2000, Nezhat et al 2005). However, Wallace (1991) reported that the factors such as obesity, pyometra or being deep-chested that may cause difficulty in the surgery were not related with ORS in companion animals since the syndrome was most common after routine ovariohysterectomies. In addition, Miller (1995) showed that the experience of the surgeon was also not associated with the syndrome because less than half of the reviewed cases had been operated on by new graduates who had received their DVM degree less than 5 years before.

Three explanations have been suggested for the development of ORS in companion animals (Feldman and Nelson 2004). The first and the most accepted explanation is incomplete surgical removal of one or both ovaries as a surgical error. This may be due to a small abdominal wall incision that makes difficult to visualize, reach and carry out the ligature of the ovary or ovaries, or to incorrect ligaturing of ovarian tissues or to anatomical location of the right ovary (Wallace 1991, Miller 1995, Johnston et al 2001 a , Prats 2001).

Anatomically, the right ovary and uterine horn are located in a more cranial position than the left ovary and uterine horn which predisposes the surgeon to leave the ovary during the surgery (Evans and Christensen 1993). The reports by Pearson (1973), Wallace (1991), and Prats (2001) demonstrated that the right ovary is more frequently found to be the remnant. However, in a study by Miller (1995), the number of the right ovary and both ovaries was found to be equal.

Dropping of some ovarian tissue into the abdomen during the surgery was suggested as a second cause of ORS (Wallace 1991, Feldman and Nelson 2004, Romagnoli 2004). If a piece of ovarian tissue is accidentally dropped into the abdomen during the surgery, this tissue revascularizes with omentum or the serosa of abdominal viscera and begins to function like a normal ovary (Prats 2001, Feldman and Nelson 2004, Romagnoli 2004). This condition has been demonstrated experimentally by Shemwell and Weed (1970) in cats, by Le Roux and Van Der Walt (1977) in dogs and by Minke et al (1994) in laboratory rats.

The third and final explanation is the presence of an accessory ovary or of ovarian tissue (ectopic) that is localized in the broad ligament (McEntee 1990, Miller 1995, Johnston et al 2001 a , Feldman and Nelson 2004). An accessory ovary is defined as an extra ovary which is located adjacent and may be connected to the normal gonad (McEntee 1990). Accessory ovary has been reported in queens (Anonymus 1977), cattle and in women (McEntee 1990). It is important to be aware of the fact that an accessory ovary may be activated if normal gonads are removed (McEntee 1990). In the bitch, ectopic tissues have been identified within the ovarian ligament at its junction with abdominal wall (Johnston et al 2001 ${ }^{\text {a }}$, and in a pregnant queen with functional corpus luteum (Prats 2001).

\section{CLINICAL SIGNS OF ORS}

Since no reports have been published describing the sufficient production of oestrogens from adrenal glands to induce oestrous signs in companion animals, any bitch displaying proestrous or oestrous signs following $\mathrm{OVH}$ should be evaluated for an ovarian residue (Prats 2001). The affected animals might show typical proestral or estral signs such as vulvar swelling, serosanguineous discharge, attractiveness to male dogs, copulation and/or signs of false pregnancy (Pearson 1973, Johnston 1991, Wallace 1991, Johnston et al 2001 ${ }^{\text {a }}$, Feldman and Nelson 2004, Romagnoli 2004, Sangster 2005). Chronic vaginitis was also reported in a three year old, toy-poodle following an OVH (Perkins and Frazer 1995).

The interval between previous OVH and the onset of signs of oestrous in bitches had a range from three months to five years (Miller 1995). It seems that the periodicity of oestrous cycles depends on the amount of the remnant tissue and its vascularization with a range of 4-to-12 months (Johnston 1991). However, in 46 ORS cases, inter- oestrous interval after OVH was detected to be 3-to36 months with an average of 8.8 months (Miller 1995).

\section{DIAGNOSIS OF ORS}

Diagnosing ORS is not an easy task, since an ectopic tissue may be localized in the broad ligament or a piece of ovarian tissue from a previous surgery may be present adjacent to its original position or somewhere in the abdominal cavity. Diagnosis is based on anamnesis, clinical symptoms, vaginal cytology, hormonal analysis, and exploratory laparotomy (Wallace 1991, Miller 1995, Johnston et al 2001 a, Prats 2001, Feldman and Nelson 2004, Romagnoli 2004). Clinical history and symptoms are very important in leading a clinician to suspect ORS (Prats 2001). However, this suspicion should be confirmed by other diagnostic tools mentioned above. Changes in circulating levels of oestradiol affect the vaginal epithelial cells and they can be monitored by vaginal cytology (Olson et al 1987, Wright 1990). Because of this, it is the cheapest, easiest and most reliable tool in the diagnosis of ORS. However, prior to vaginal cytologic examination, it is crucial to verify that the bitch is not using exogenous oestrogens for the treatment of urinary incontinence (Wallace 1991). The vaginal smear should be performed when the animal shows signs of oestrous otherwise the majority of the cells would be parabasal and basal which will not reflect any functional ovarian tissue. In the presence of a functional ovarian remnant, oestrogen secretion will cause a progressive cornification of the vaginal epithelial cells (Wallace 
1991). A vaginal smear of a bitch with ORS should have a dominance of approximately $80-90 \%$ of superficial cells (Wallace 1991, Johnston et al 2001 ${ }^{\mathrm{b}}$, Prats 2001, Feldman and Nelson 2004, Romagnoli 2004). Vaginal cytologic image of a spayed, 9 years old German Shepherd bitch which was presented with vaginal bleeding six years after the surgery, is shown in figure 1 . Notice the dominance of nucleated superficial epithelial cells and red blood cells on the slide, demonstrating that the bitch was in late proestrous, although she was spayed.

Levels of two gonadal hormones, oestradiol and progesterone, should be measured to determine the presence of an ovarian tissue. Serum oestradiol levels higher than $10-20 \mathrm{pg} / \mathrm{ml}$ or serum progesterone concentrations above $2 \mathrm{ng} / \mathrm{ml}$ are indicative of a functional ovarian tissue (Wallace 1991). Serum oestradiol concentrations of the German Shepherd bitch with ORS mentioned above was 55 pg/ml. Le Roux and Van Der Walt (1977), autotransplanted the ovaries to the portal vein drainage area in four adult bitches. The mean oestradiol levels of these animals were found higher than ovariectomized bitches $(91 \pm 28$ vs. $64 \pm 19 \mathrm{pg} / \mathrm{ml})$ and the mean progesterone levels were determined higher as well ( $81 \pm 31$ vs. $68 \pm 32 \mathrm{ng} / \mathrm{ml}$ ). Wallace (1991), indicated that progesterone measurement would be more indicative than oestradiol since the only progesterone source in the bitch is the ovary. Progesterone measurement should be performed after the proestral or oestral signs have ceased.

Provocative progesterone testing with hCG or GnRH is another valuable approach in ORS. Serum progesterone concentrations should be measured at presentation and one or two weeks after induction of ovulation using $\mathrm{GnRH}$ at a dose of $2.2 \mu \mathrm{g} / \mathrm{kg}$ or hCG at $50 \mathrm{IU} / \mathrm{kg}$ (Prats 2001, Romagnoli 2004). If there is an ovarian tissue left in the abdomen, serum oestradiol levels are expected to drop and progesterone levels to rise after the ovulation induction (Perkins and Frazer 1995, Prats 2001, Feldman and Nelson 2004).

In humans, the widespread use of diagnostic technologies such as ultrasonography or computed tomography increased and improved the diagnosis of ORS and as consequence of that more cases were discovered due to the techniques (Petit and Lee 1988). Although ultrasonography is routinely used in women to confirm the presence of the remnant, to determine the localization and the size of the mass, it is considered to be an unnecessary diagnostic tool in companion animals due to the small size of the remnant tissue (Johnston et al 2001 ${ }^{\mathrm{a}}$, Romagnoli 2004). In a report by Pettit and Lee (1988), the location and the size of the pelvic mass was determined in 21 of 23 women $(91.3 \%)$ by ultrasonography. This valuable tool can also be used in medium to large breed dogs for the same purposes. Figure 2 shows the ultrasonographic image of the right remnant ovary with follicle formations from a 6 years old Golden Retriever bitch, which was presented with vaginal bleeding, allowance to mate, attractiveness to male dogs and continous oestrous behaviour every 5-to-6 months following $\mathrm{OVH}$ about two years before.

Moreover, the presence and the condition of the uterine remnant after $\mathrm{OVH}$ can also be evaluated by ultra-

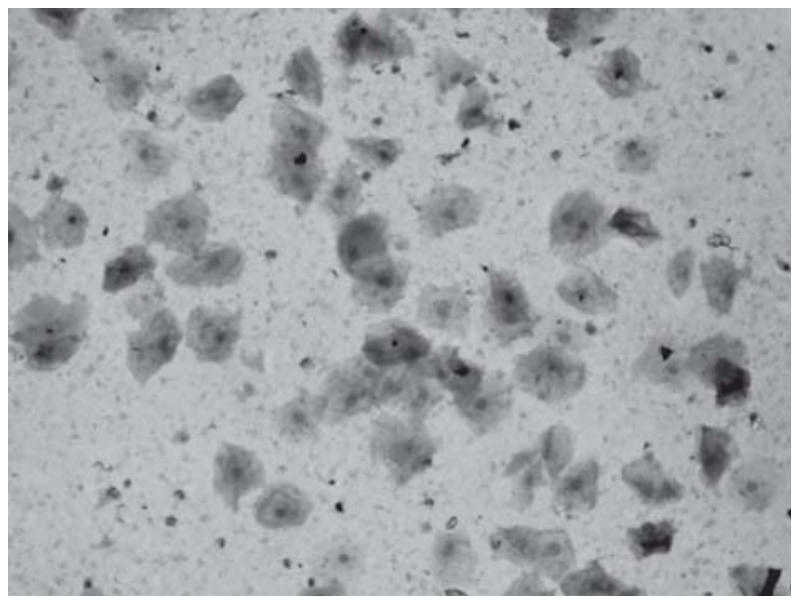

Figure 1. Vaginal smear of a German Shepherd bitch with ORS, illustrating superficial cells with pyknotic nuclei and red blood cells (stained with Giemsa).

Frotis vaginal de una perra Pastor Alemán con ORS, mostrando células superficiales con núcleo picnótico y eritrocitos (teñido con Giemsa).

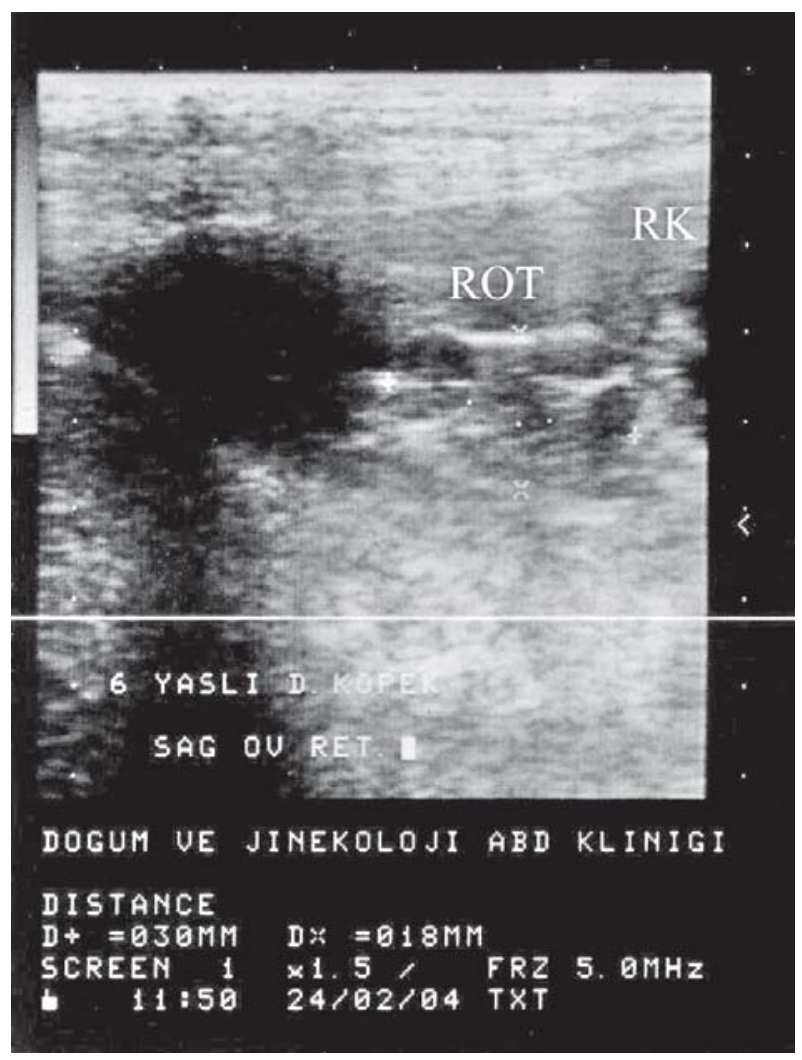

Figure 2. Follicle development on the right ovarian remnant tissue (ROT) localized caudal to right kidney (RK).

Desarrollo folicular en el tejido remanente del ovario derecho (ROT) localizado caudal al riñón derecho (RK). 
sonography. A stump uterine granuloma was determined by ultrasonography in a 7 years old Cocker Spaniel bitch with right side ORS that had OVH when she was two (figure 3).

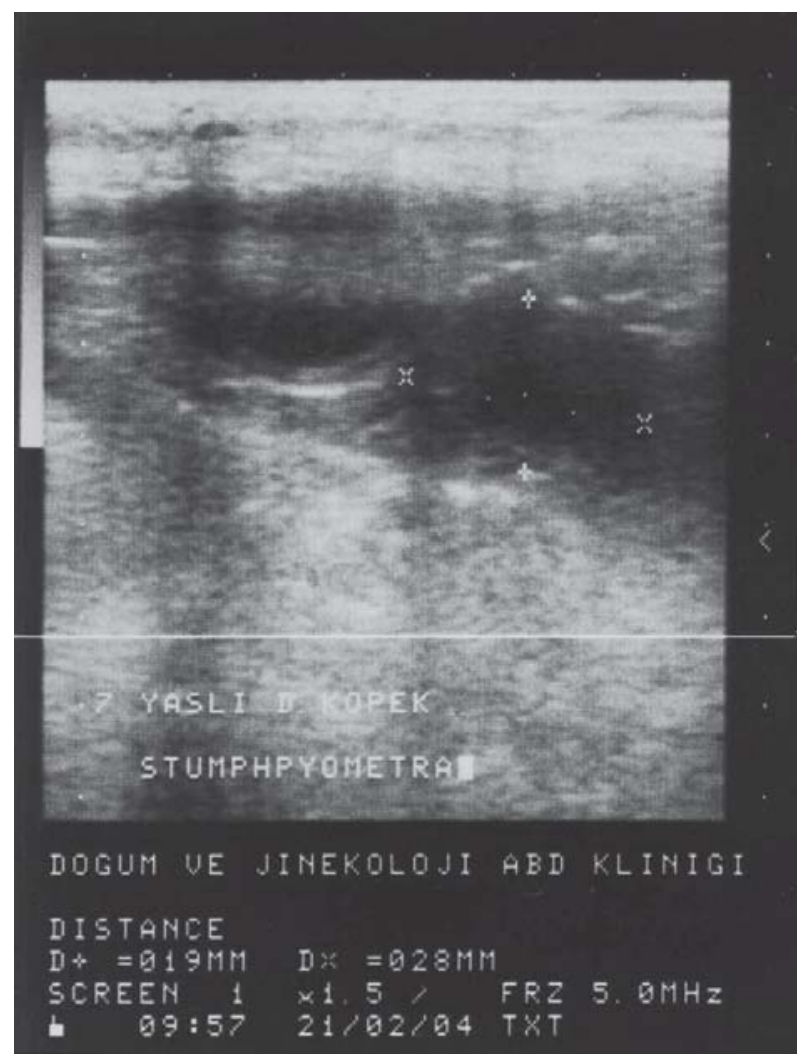

Figure 3. Ultrasonographic image of uterine stump pyometra in a 7 years old Cocker Spaniel bitch with ORS.

Imagen ultrasonográfica de una piómetra en muñón uterino en una perra Cocker Spaniel de 7 años con ORS.
Differential diagnosis for ORS are the conditions that cause bloody vulvar discharge including vaginal neoplasia, vaginitis, uterine stump pyometra, trauma, exogenous estrogen therapy and coagulopathy (table 1).

\section{TREATMENT OF ORS}

Prior to the onset of any treatment, the exogenous oestrogen administration for therapeutic reasons, such as urinary incontinence, should be ruled out. The only recommended treatment for ORS is surgical removal of the remnant tissue (Perkins and Frazer 1995, Johnston et al $2001^{\text {a }}$, Prats 2001, Feldman and Nelson 2004, Romagnoli 2004). Although not recommended, lifelong medical treatment with oestrous suppressing drugs could be considered if the owner is not willing to accept a surgery or if the previous surgical attempts have failed to solve the problem.

Lifelong usage of megestrol acetate or mibolerone has been mentioned in the medical treatment of ORS (Johnston et al 2001'a, Feldman and Nelson 2004, Romagnoli 2004). The side effects of progestagens such as increasing the incidence of mammary gland tumors (Briggs 1980, Van Os et al 1981, Bruun 1997), induction of growth hormone secretion and promotion of acromegaly (Scott and Concannon 1983), and suppression of adrenocortical function (Van den Broek and O'Farrell 1994), rule out medical treatment with these compounds. Also, practical concerns of medical treatment with progestagens such as cost or two applications per year are mentioned by Romagnoli (2004). Moreover, medical treatment with mibolerone is also not recommended since it may cause clitoral enlargement, vaginal discharge, or behavioral changes (Evans and Sutton 1989). Furthermore, no reports have been published on any progestagen

Table 1. Differential diagnosis of ORS.

Diagnóstico diferencial de ORS.

\begin{tabular}{lcccc}
\hline & ORS & Adult vaginitis & Vaginal neoplasia & Uterine stump pyometra \\
\hline Breed Predisposition & No & No & $\begin{array}{c}\text { Boxer, German Shepherd } \\
\text { and mixed breed }\end{array}$ & No \\
\hline Age & $1-9$ years & $>1$ years & $10.8-11.2$ years & $3-13$ years \\
\hline Vulvar Swelling & Yes & No & No & Yes \\
\hline $\begin{array}{l}\text { Vulvar Discharge/ } \\
\text { Characteristic }\end{array}$ & $\begin{array}{c}\text { Yes/mucoid- } \\
\text { Serosanguineous }\end{array}$ & $\begin{array}{c}\text { Yes/Mucoid- } \\
\text { purulent }\end{array}$ & $\begin{array}{c}\text { Yes/mucoid, } \\
\text { mucopurulent, } \\
\text { sanguineous }\end{array}$ & $\begin{array}{c}\text { Yes/purulent or } \\
\text { sanguinopurulent }\end{array}$ \\
\hline Oestrous Behaviour & Yes & No & No & Yes, if ovarian \\
tissue is left
\end{tabular}


or mibolerone used in medical treatment for ORS with success. However, medroxyprogesterone acetate, alone or with estrogen, has been used as a non-surgical therapy in humans (Nelson and Avant 1982, Steege 1987).

Romagnoli, (2004) suggested the use of GnRH agonists as another option for the medical treatment of ORS. The application of GnRH agonists cause a high increase in LH and FSH levels which continues for some days and then returns to basal levels. However, long-term application of these products causes down regulation of $\mathrm{GnRH}$ receptors resulting in the ceasation of pulsatile secretion of LH, the follicular development is inhibited and oestrogen concentration sufficient enough to induce the positive feedback and ovulation is also inhibited (Herbert and Trigg 2005). Deslorelin, a GnRH agonist has been used successfully in canine and feline reproduction to control the reproductive function (Munson et al 2001, Trigg et al 2001), to induce oestrous (Kutzler et al 2002), or ovulation (Romagnoli et al 2002). Except for a minimal oedema at the site of application, no serious side effects of deslorelin have been reported. However, the effects of this drug in the medical treatment of ORS are unknown.

Today, the best way to treat the syndrome is surgical excision of the remnant tissue. In humans, $16 \%$ of surgical complication rate was reported by Petit and Lee (1988), whereas at least $30 \%$ was reported by Steege (1987). The complication rate of surgical removal of the remnant tissue in dogs is unknown. For the surgical approach, a mid-line ventral laparotomy is preferred instead of a flank incision. A mid-line ventral laparotomy would provide clear visualization of the abdominal cavity which would make the surgery easier. Moreover, by mid-line approach, it would be possible to remove the remnant uterine tissue if present.

The timing of the exploratory laparotomy is very important. It will be much easier to detect the ovarian tissue, if the animal is under the influence of oestrogen or if the ovulation has occurred. In both cases, the ovary will be enlarged because of the follicles or corpora lutea. However, due to the increased vascularity, intraoperative bleeding could be a complication. Although the intraoperative bleeding will be less in the luteal phase, postoperative false pregnancy may be induced (Perkins and Frazer 1995, Johnston et al 2001'a, Prats 2001, Feldman and Nelson 2004). Laparotomy is not recommended during anestrous, since the remnant tissue might be too small to be detected (Wallace 1991, Perkins and Frazer 1995). Harvey (1998), suggests that the best timing for the surgery would be two weeks after attractiveness has ceased in which oestrogen and prolactin concentrations would be at basal levels. However, Wallace (1991), prolongs the surgery time, until 50 days after oestrous.

The abdominal incision should be more cranial than for routine OVH. During the surgery, the caudal poles of both kidneys, the broad ligament, the omentum and the abdominal wall should be examined deeply to identify any ovarian tissue. Moreover, the ligature site at the uterine-cervical junction should be inspected to identify any pathological condition of the uterus as uterine horn or uterine body may be remnant as well (Manfra-Marretta et al 1989). It was demonstrated by Miller (1995), that in most cases ovarian remnants were located around the ovarian pedicles. If no ovarian tissue can be detected then granulation tissue at each ovarian pedicle should be excised. Histopathology of any resected tissue has a crucial importance in ORS, since granulosa cell tumor has been reported in a 7.5 year old Golden Retriever which had an OVH about 7 years before (Pluhar et al 1995).

The prognosis is good if the remnant tissue is totally removed. The clinical symptoms should cease after the removal of the ovarian remnant. There is no published data reporting recurrence of ORS in companion animals; however, the recurrence rate of ORS in women is estimated to be $8-25 \%$ in one report (Nezhat et al 2005), and 8-10\% in another (Lafferty et al 1996).

\section{CONCLUSION}

Prevention is the best way to avoid the development of the ovarian remnant sydrome. Sufficient abdominal wall incision to visualize the surgical area, proper ligation of the reproductive organs and total removal of both ovaries without leaving any ovarian tissue have crucial importance in prevention of the syndrome. Early age neutering or prepubertal ovariohysterectomy can be considered another preventive factor since the syndrome is not detected in animals spayed younger than four months.

\section{SUMMARY}

Ovarian remnant sydrome is a well-known long-term complication of ovariectomy or ovariohysterectomy which is caused by the presence of an active ovarian tissue despite an elective surgery. As a result of leaving or dropping some ovarian tissue in the abdomen or because of an ectopic ovarian tissue, typical clinical signs of proestrous or oestrous, such as swollen vulva, proestral bleeding or behavioral changes develop. The diagnostic approaches are vaginal cytology, gonadal hormone measurements, ultrasonography and exploratory surgery. Surgical excision of the ovarian mass is the recommended treatment which is a difficult process. This paper describes the causes of the syndrome, the clinical presentation of the patient, the diagnosis and the treatment of ovarian remnant syndrome in dogs.

\section{REFERENCES}

Anonymous. 1977. Third ovary in a cat: A case report. Mod Vet Pract, 58. Briggs MH. 1980. Progestogens and mammary tumors in the beagle bitch. Res Vet Sci 28, 199-202.

Bruun ET. 1997. Oestrus control in the bitch with medroxyprogesterone acetate (MPA) and the prevalence of mammary tumors. EJCAP 7, 59-63.

Concannon PW, VN Meyers-Wallen. 1991. Current and proposed methods for contraception and termination of pregnancy in dogs and cats. J Am Vet Med Assoc 198, 1214-1225. 
Concannon PW. 1995. Reproductive endocrinology, contraception and pregnancy termination in dogs. In: Ettinger, S.J. and Feldman, E.C (eds.). Textbook of Veterinary Internal Medicine. Fourth edition. WB Saunders Company, Philadelphia, USA, Pp 1625-1636.

Dorn AS, RA Swist. 1977. Complications of canine ovariohysterectomy. J Am Anim Hosp Assoc 13, 720-724.

Evans HE, GC Christensen. 1993. The urogenital system. In: Christensen, G.C., Evans, H.E. (eds): Miller's Anatomy of the Dog. 3rd edition, W.B.Saunders Company, Philadelphia, USA, Pp 494-558.

Evans JM, DJ Sutton. 1989. The use of hormones, especially progestagens, to control oestrus in bitches. J Reprod Fertil (Suppl) 39, 163-173.

Feldman EC, RW Nelson. 2004. Ovarian remnant syndrome. In: Feldman, E.C. and Nelson, R.W. (eds.) Canine and Feline Endocrinology and Reproduction. 3rd edition, W.B. Saunders Company, 11830 Westline Industrial Drive, St. Luis, Missouri, USA, Pp 892-893.

Harvey M. 1998. Conditions of the non-pregnant female. In: Simpson, G.M. (general ed.), England, G.C.W., Harvey, M. (scientific eds.) BSAVA Manual of Small Animal Reproduction and Neonatology, Shurdington, Cheltenham, UK, Pp 35-53.

Herbert CA, TE Trigg. 2005. Applications of GnRH in the control and management of fertility in female animals. Anim Reprod Sci $88,141-153$

Johnston SD, MVR Kustritz, PNS Olson. 2001a. Ovarian remnant syndrome. In: Johnston, S.D., Kustritz, M.V.R., Olson, P.N.S (eds.) Canine and Feline Theriogenology. W.B. Saunders Company, 11830 Westline Industrial Drive, St. Louis, Missouri, USA, Pp 199-200.

Johnston SD, MVR Kustritz, PNS Olson. 2001b. Vaginal cytology. In: Johnston, S.D., Kustritz, M.V.R., Olson, P.N.S. (eds.) Canine and Feline Theriogenology. W.B. Saunders Company, 11830 Westline Industrial drive, St. Louis, Missouri, USA, Pp 32-38.

Johnston SD. 1991. Questions and answers on the effects of surgically neutering dogs and cats. $J$ Am Vet Med Assoc 198, 1206-1214.

Kamprath S, M Possever, A Schneider. 1997. Description of a laparoscopic technique for treating patients with ovarian remnant syndrome. Fertil Steril 68, 663-667.

Kaufmann JJ. 1962. Unusual causes of extrinsic ureteral obstruction. Part 1. J Urology 97, 319-327.

Kutzler MA, R Wheeler, SV Lamb, DH Volkmann. 2002. Deslorelin implant administration beneath the vulvar mucosa for the induction of synchronous estrus in bitches. Proceedings of Third EVSSAR European Congress, Liege, Belgium, Pp 96.

Lafferty HW, R Angioli, J Rudolph, MA Penalver. 1996. Ovarian remnant syndrome: Experience at Jackson Memorial Hospital, University of Miami, 1985 through 1993. Am J Obstet Gynecol 174, 641-645.

Le Roux PH, LA Van Der Walt. 1977. Ovarian autografts as an alternative to ovariectomy in bitches. J S Afr Vet Assoc 48, 117-123.

Manfra-Marretta S, DT Matthiesen, CE Nichols. 1989. Pyometra and its complications. Probl Vet Med 1, 50-62.

McEntee K. 1990. Congenital anomalies. In: McEntee, K. (ed), Reproductive Pathology of Domestic Mammals. Academic Press Inc, San Diego, California, USA, Pp 36-41.

Miller DM. 1995. Ovarian remnant syndrome in dogs and cats: 46 cases (1988-1992). J Vet Diagn Invest 7, 572-574

Minke T, W DePond, T Winkelmann, J Blythe. 1994. Ovarian remnant syndrome: study in laboratory rats. Am J Obstet Gynecol 171 , 1440-1444.

Munson L, JE Bauman, CS Asa, W Jöchle, TE Trigg. 2001. Efficacy of the GnRH analogue deslorelin for suppression of oestrous cycles in cats. J Reprod Fertil (Suppl) 57, 269-273.

Nelson DC, GR Avant. 1982. Ovarian remnant syndrome. South Med $J$ 75, 757-758.

Nezhat C, S Kearney, S Malik, C Nezhat, F Nezhat. 2005. Laparoscopic management of ovarian remnant. Fertil Steril 83, 973-978.
Nezhat C, DS Seidman, FR Nezhat, SA Mirmalek, CR Nezhat. 2000 Ovarian remnant syndrome after laparoscopic oophorectomy. Fertil Steril 74, 1024-1028.

Okkens A, S Dielman, I Vander Gaag. 1981a. Gynaecological complications following ovariohysterectomy in dogs, due to partia removal of the ovaries or inflammation of the uterocervical stump. Tijdschr Diergeneeskd 106, 1142-1158.

Okkens A, S Dielman, I Vander Gaag. 1981b. Urologic complications following ovariohysterectomy in dogs. Tijdschr Diergeneeskd 106 , 1189-1198

Okkens AC, HS Kooistra, RF Nickel. 1997. Comparison of long-term effects of ovariectomy versus ovariohysterectomy in bitches. J Reprod Fertil (Suppl) 51, 227-231.

Olson PN, MD Behrendt, DE Weiss. 1987. Reproductive problems in the bitch: finding answers through vaginal cytology. Vet Med April, 344-351.

Pearson H. 1973. The complications of ovariohysterectomy in the bitch J Small Anim Pract 14, 257-266.

Perkins NR, GS Frazer. 1995. Ovarian remnant syndrome in toy poodle a case report. Theriogenology 44, 307-312.

Pettit PD, RA Lee. 1988. Ovarian remnant syndrome: diagnostic dilemma and surgical challenge. Obstet Gynecol 71, 580-583.

Pluhar GE, MA Memon, LG Wheaton. 1995. Granulosa cell tumor in an ovariohysterectomized dog. J Am Vet Med Assoc 207 1063-1065.

Pollari FL, BN Bonnett, CB Sheena, AH Meek, DG Allen. 1996 Postoperative complications of elective surgeries in dogs and cats determined by examining electronic and paper medical records $J$ Am Vet Med Assoc 208, 1882-1886.

Prats AE. 2001. Ovarian remnant sydrome in the queen. EVSSAR Newsletter 4, Pp 5-8.

Romagnoli S, P Frumento, F Abramo. 2002. Induction of ovulation in the estrous queen with GnRH: a clinical study. Proceedings of Third EVSSAR European Congress, Liege, Belgium, Pp160-1.

Romagnoli S. 2004. Ovarian remnant syndrome. Proceedings of Fourth EVSSAR Congress, Barcelona, Spain, Pp 239-241.

Salmeri KR, PN Olson, MS Bloomberg. 1991. Elective gonadectomy in dogs: A review. J Am Vet Med Assoc 198, 1183-1192.

Sangster C. 2005. Ovarian remnant syndrome in a 5 year old bitch. Can Vet J 46, 62-64.

Scott DW, PW Concannon. 1983. Gross and microscopic changes in the skin of dogs with progestagen-induced acromegaly and elevated growth hormone levels. J Am Anim Hosp Assoc 19, 523-527.

Shemwell RE, JC Weed. 1970. Ovarian remnant syndrome. Obstet Gynecol 39, 299-303

Steege JF. 1987. Ovarian remnant syndrome. Obstet Gynecol 70 64-67.

Stone EA, CG Cantrell, NJH Sharp. 2003. Ovary and uterus. In: Slatter D (ed), Textbook of Small Animal Surgery. 2nd edition, W.B.Saunders Company, Philadelphia, USA, Pp 1293-1308.

Trigg TE, PJ Wright, AF Armour, PE Williamson, A Junaidi, GB Martin, AG Doyle, J Walsh. 2001. Use of a GnRH analogue implant to produce reversible long-term suppression of reproductive function in male and female domestic dogs. J Reprod Fertil (Suppl) 57, 255-261.

Van den Broek AHM, V O'Farrell. 1994. Suppression of adrenocortical function in dogs receiving therapeutic doses of megestrol acetate. $J$ Small Anim Pract 35, 285-288.

Van Os JL, PH Van Laar, EP Oldenkamp, JSC Verschoor. 1981 Oestrus control and the incidence of mammary nodules in bitches, a clinical study with two progestagens. Vet Quart 3, 46-56.

Wallace MS. 1991. The ovarian remnant syndrome in the bitch and queen. Vet Clin North Am 21, 501-507.

Wright PJ. 1990. Application of vaginal cytology and plasma progesterone determinations to the management of reproduction in the bitch. J Small Anim Pract 31, 335-340. 